\title{
PREVALENCE OF METHICILLIN RESISTANT STAPHYLOCOCCUS AUREUS (MRSA) IN MOLOUHA (SALTED FISH)
}

\author{
LUBNA MOHAMED IBRAHIM and MANAL HASSAN THABET \\ Animal Health Research Institute (Assiut lab.)
}

Received: 16 June 2016; Accepted: 8 August 2016

\begin{abstract}
Fifty samples of Salted Hydrocynus Froskalli Fish (Molouha) were subjected for enumeration, isolation and identification of Staph.aureus. 34 strains (68\%) of Staph.aureus were isolated, $16(32 \%)$ were coagulase positive and $18(36 \%)$ were coagulase negative, the mean Staph.aureus count was $35 \times 10^{3} \mathrm{cfu} / \mathrm{g}$. It was found that $46 \%$ of examined samples were unaccepted based on the Egyptian Organization for standardization and quality control. The antimicrobial sensitivity revealed that isolated coagulase positive Staph.aureus were resistance to Neomycin, Penicillin, Kanamycin, Ampicillin, Chloramphenicol, Erythromycin, Oxytetracycline, Cloxacillin, Sulphamethoxazol, Ciprofloxacin, Cephalothin, Gentamicin, Methicillin and Vancomycin with a percentage of $100,100,93.7,81.3,75.0,62.5,56.3,56.3,50.0,43.7,37.5,25.0,25.0$ and $6.3 \%$ respectively, whereas the high resistance rate was observed against Neomycin and Penicillin $(100 \%)$ and the isolates showed 11 different patterns of antimicrobial sensitivity, whereas the high sensitive rate was observed with vancomycin $(87.5 \%)$. Detection of mecA gene was done for all coagulase positive Staph.aureus strains (16) by PCR using specific primer with amplification length of $533 \mathrm{pb}$. The obtained results showed that all (MRSA) isolates were positive for presence of mecA gene and one of these isolets could not produce enterotoxin, whereas two could produce SEA and one could produce SEC.
\end{abstract}

Key words: Prevalence, Methicillin, Staphylococcus aureus and Salted fish.

\section{INTRODUCTION}

There is increasing demand for fish and fish products around the world (Feldhusen, 2000). However, there is substantial evidence that fish and seafood are high on the list of foods associated with outbreaks of food born diseases (Huss and Valdimarsson, 1990), that fish acts as a vehicle for many types of microorganisms from its natural aquatic enviroment, sewage, soil contaminated harvesting areas, contaminated utensils during handling, processing, distrubution and storage (Shwewan, 1971). Staphylococci are among the most widspread pathogenic and apportunist pathogenic bacteria, it is an extraordinary versatile pathogen however, coagulase negative staphyococci causes bacteremia, endocarditis, catheter related infections, centeral nervous system shunt infections, urinary tract infections, endophthalmitis and the major causative agent of neumerous hospital and community acquired infections (Van et al., 2007 and Doškař et al., 2010).

Staph.aureus known as salt tolerant bacteria (Shena and Sanjecv, 2007). It is well known by its ability to

Corresponding author: Dr. LUBNA MOHAMED IBRAHIM

E-mail address:ghada02468@yahoo.com

Present address:Animal Health Research Institute (Assiut lab.) acquire antibiotic resistant, both historically in relation to penicillin, erythromycin and tetracycline and more recently methicillin and vancomycin resistance (Gaze et al., 2008).

Methicillin resistant Staph. aureus (MRSA) emerged as a nosocomial pathogen in the early 1960s and spread worldwide, they found that MRSA was far more common in the environment than previously understood, even in lakes and rivers ( Fluit et al., 2001). Methicillin is the first semisynthetic penicillin to be developed, was introduced in 1959 to overcome the problem of pencillin-resistant Staph.aureus due to $\beta$-lactamase (pencillinase) production (Livermore, 2000). Afterwords, worldwide MRSA epidemic has occured, that can affect vital organs and lead to widespread infection (sepsis), toxic shock syndrome and necrotizing (flesh-eating), pneumonia. This is thought to be due to toxins carried by CA-MRSA strains (community-associated MRSA) (Wulf and Voss, 2008) and recently these organisms have evolved and emerged as a major cause of community - acquired infectious strains which contain the mecA gene with or without additional antibiotic resistance genes and are more easily transferred to other strains of Staph.aureus (O'brien et al. 2004). 
Soliman, et al. (2014) reported the presence of (MRSA) associated with mortalities during an outbreak by consuming Nile Tilapia fish in Egypt.

Molouha is a popular Egyptian salted fish highly consumed in Upper Egypt, and due to lack of researches on (MRSA) isolated from salted fish, this current study designed to shed some light on (MRSA) isolated from the Egyptian salted fish (Molouha), their antibiogram for antibiotic sensitivity and molecular identification using PCR, with detection and typing of Staph.aureus enterotoxins.

\section{MATERIAL AND METHODS}

1) Collection of samples:

A total of 50 random samples of Molouha (salted Hydrocynus Froskalli fish) were collected from different local markets with different sanitation levels at Assiut governorate. All the collected samples were then transferred to the laboratory under complete aseptic conditions without undue delay where they were prepared and examined.

\section{2) Isolation and Bacteriological count of} Staph.aureus:

Twenty Five gm from each sample of salted Hydrocynus Froskalli were blended in a stomacher for $1 \mathrm{~min}$. In $225 \mathrm{ml}$. of $0.1 \%$ sterile peptone water at 3000 r.p.m. Decimal dilution were carried out using the same diluents, the spread plate technique was used to prepare duplicate plates for determination of Staph.aureus on Baird Parker plates, which incubted under aerobic condition at $37^{\circ} \mathrm{c}$ for $24 \mathrm{~h}$., plates between 25 and 250 colonies were counted and mean counts were calculated according to (APHA, 2001).

\section{3) Identification:}

Staph.aureus was confirmed using cell morphology, arrangment of cells, gram reaction, catalase test, modified oxidase test, Coagulase activity, acid production (maltose, manitol and aceton production test) according to (Baird-Parker, 1980) and (Quinn et al., 2002).

4) Acceptability of the examined samples for Staph. aureus count:

Were determined according to (EOS, 2005).

5) Antibiogramme for antibiotic sensitivity of isolated coagulase +ve Staph.aureus:

Antimicrobial susceptibility was tested by the single diffusion method according to (Deresse et al., 2012).

The antimicrobial susceptibility testing was applied according to the guidelines stipulated by National committee for Clinical Laboratory Standards (NCCLS, 2001).

6) Multiple Antibiotic Resistance (MAR) index: Was determined according to the formula stipulated by (Singh et al., 2010).

\section{7) Polymerase Chain Reaction (PCR):}

Benha university, Faculty of Veterinary Medicine, Food Analysis Center.

a. Primer sequences of Staph.aureus used for PCR system according to (El Karamany et al., 2013) table (5).

b. DNA Extraction using QIA amp. Kit according to (Prez-Roth et al., 2001)

c. Amplification reaction of Staph.aureus according to (Murakami et al., 1991)

8) Detection and typing of Staph.aureus enterotoxins according to (Rose et al., 1989).

\section{RESULTS}

Table 1: Number and incidence of S.aureus in salted Hydrocynus froskalli.

\begin{tabular}{ccccccccc}
\hline \multirow{2}{*}{$\begin{array}{c}\text { Number of } \\
\text { samples }\end{array}$} & \multicolumn{3}{c}{ S.aureus isolates } & \multicolumn{3}{c}{ Coagulase } \\
\cline { 2 - 9 } & \multicolumn{2}{c}{ Positive } & \multicolumn{2}{c}{ Negative } & \multicolumn{2}{c}{ Positive } & Negative \\
\cline { 2 - 9 } & No & $\%$ & No & $\%$ & No & $\%$ & No & $\%$ \\
\hline 50 & 34 & 68 & 16 & 32 & 16 & 32 & 18 & 36 \\
\hline
\end{tabular}

Table 2: Statistical analytical results of S.aureus in salted Hydrocynus froskalli.

\begin{tabular}{cccccccc}
\hline \multirow{2}{*}{$\begin{array}{c}\text { Number of } \\
\text { samples }\end{array}$} & \multicolumn{2}{c}{ S.aureus cfu/g } & \multicolumn{2}{c}{$\begin{array}{c}\text { Acceptable } \\
\text { samples* }\end{array}$} & \multicolumn{2}{c}{$\begin{array}{c}\text { Unacceptable } \\
\text { samples* }\end{array}$} \\
\cline { 2 - 8 } & Min & Max & Mean & No & $\%$ & No & $\%$ \\
\hline $\mathbf{5 0}$ & $1 \times 10$ & $7 \times 10^{5}$ & $35 \times 10^{3} \pm 21 \times 10^{3}$ & 27 & 54 & 23 & 46 \\
\hline
\end{tabular}

* According to maximum permissible limit (100MPC/g) stipulated by EOS, (2005) 
Table 3: Percentages of Antimicrobial susceptibility of coagulase +ve Staph.aureus $(\mathrm{n}=16)$.

\begin{tabular}{lcccccc}
\hline \multirow{2}{*}{ Antimicrobial agent } & \multicolumn{2}{c}{$\mathrm{S}$} & $\mathrm{N}$ & $\mathrm{I}$ & $\mathrm{R}$ \\
\cline { 2 - 7 } & No & $\%$ & - & $\%$ & No & $\%$ \\
\hline Neomycin (N) & - & - & - & - & 16 & 100 \\
\hline Penicillin (P) & - & - & - & - & 16 & 100 \\
\hline Kanamycin (K) & - & - & 1 & 6.3 & 15 & 93.7 \\
\hline Ampicillin (AM) & 1 & 6.3 & 2 & 12.5 & 13 & 81.3 \\
\hline Chloramphenicol (C) & 3 & 18.8 & 1 & 6.3 & 12 & 75.0 \\
\hline Erythromuycin (E) & 3 & 18.8 & 3 & 18.8 & 10 & 62.5 \\
\hline Oxytetracycline (T) & 5 & 31.3 & 2 & 12.5 & 9 & 56.3 \\
\hline Cloxacillin (CL) & 6 & 37.5 & 1 & 6.3 & 9 & 56.3 \\
\hline Sulphamethoxazol (SXT) & 4 & 25.0 & 4 & 25.0 & 8 & 50.0 \\
\hline Ciprofloxacin (CP) & 6 & 37.5 & 3 & 18.8 & 7 & 43.7 \\
\hline Cephalotin (CN) & 8 & 50.0 & 2 & 12.5 & 6 & 37.5 \\
\hline Gentamicin (G) & 9 & 56.3 & 3 & 18.8 & 4 & 25.0 \\
\hline Methicicillin (M) & 10 & 62.5 & 2 & 12.5 & 4 & 25.0 \\
\hline Vancomycin (VA) & 14 & 86.5 & 1 & 6.3 & 1 & 6.3 \\
\hline
\end{tabular}

Table 4: Antimicrobial resistance profile of Staph.aureus strains $(\mathrm{n}=16)$.

\begin{tabular}{clc}
\hline \multicolumn{1}{c}{ Strains } & \multicolumn{1}{c}{ Antimicrobial resistance profile } & MAR index \\
\hline Staph.aureus & $\mathrm{N}, \mathrm{P}, \mathrm{K}, \mathrm{AM}, \mathrm{C}, \mathrm{E}, \mathrm{T}, \mathrm{CL}, \mathrm{SXT}, \mathrm{CP}, \mathrm{CN}, \mathrm{G}, \mathrm{M}, \mathrm{VA}$ & 1 \\
\hline Staph.aureus & $\mathrm{N}, \mathrm{P}, \mathrm{K}, \mathrm{AM}, \mathrm{C}, \mathrm{E}, \mathrm{T}, \mathrm{CL}, \mathrm{SXT}, \mathrm{CP}, \mathrm{CN}, \mathrm{G}, \mathrm{M}$ & 0.928 \\
\hline Staph.aureus & $\mathrm{N}, \mathrm{P}, \mathrm{K}, \mathrm{AM}, \mathrm{C}, \mathrm{E}, \mathrm{T}, \mathrm{CL}, \mathrm{SXT}, \mathrm{CP}, \mathrm{CN}, \mathrm{G}, \mathrm{M}$ & 0.928 \\
\hline Staph.aureus & $\mathrm{N}, \mathrm{P}, \mathrm{K}, \mathrm{AM}, \mathrm{C}, \mathrm{E}, \mathrm{T}, \mathrm{CL}, \mathrm{SXT}, \mathrm{CP}, \mathrm{CN}, \mathrm{G}, \mathrm{M}$ & 0.928 \\
\hline Staph.aureus & $\mathrm{N}, \mathrm{P}, \mathrm{K}, \mathrm{AM}, \mathrm{C}, \mathrm{E}, \mathrm{T}, \mathrm{CL}, \mathrm{SXT}, \mathrm{CP}, \mathrm{CN}$ & 0.786 \\
\hline Staph.aureus & $\mathrm{N}, \mathrm{P}, \mathrm{K}, \mathrm{AM}, \mathrm{C}, \mathrm{E}, \mathrm{T}, \mathrm{CL}, \mathrm{SXT}, \mathrm{CP}, \mathrm{CN}$ & 0.786 \\
\hline Staph.aureus & $\mathrm{N}, \mathrm{P}, \mathrm{K}, \mathrm{AM}, \mathrm{C}, \mathrm{E}, \mathrm{T}, \mathrm{CL}, \mathrm{SXT}, \mathrm{CP}$ & 0.714 \\
\hline Staph.aureus & $\mathrm{N}, \mathrm{P}, \mathrm{K}, \mathrm{AM}, \mathrm{C}, \mathrm{E}, \mathrm{T}, \mathrm{CL}, \mathrm{SXT}$ & 0.643 \\
\hline Staph.aureus & $\mathrm{N}, \mathrm{P}, \mathrm{K}, \mathrm{AM}, \mathrm{C}, \mathrm{E}, \mathrm{T}, \mathrm{CL}$ & 0.571 \\
\hline Staph.aureus & $\mathrm{N}, \mathrm{P}, \mathrm{K}, \mathrm{AM}, \mathrm{C}, \mathrm{E}, \mathrm{T}$ & 0.500 \\
\hline Staph.aureus & $\mathrm{N}, \mathrm{P}, \mathrm{K}, \mathrm{AM}, \mathrm{C}$ & 0.357 \\
\hline Staph.aureus & $\mathrm{N}, \mathrm{P}, \mathrm{K}, \mathrm{AM}, \mathrm{C}$ & 0.357 \\
\hline Staph.aureus & $\mathrm{N}, \mathrm{P}, \mathrm{K}, \mathrm{AM}$ & 0.286 \\
\hline Staph.aureus & $\mathrm{N}, \mathrm{P}, \mathrm{K}$ & 0.214 \\
\hline Staph.aureus & $\mathrm{N}, \mathrm{P}, \mathrm{K}$ & 0.214 \\
\hline Staph.aureus & $\mathrm{N}, \mathrm{P}$ & 0.143 \\
\hline
\end{tabular}

Table 5: Primers used for detection of $m e c A$ gene.

\begin{tabular}{|c|c|c|c|}
\hline Target gene & Oligonucleotide sequence $\left(5^{\prime} \rightarrow 3^{\prime}\right)$ & Product size (bp) & References \\
\hline $\operatorname{MecA}(\mathrm{F})$ & 5' AAAATCGATGGTAAAGGTTGGC'3 & \multirow{2}{*}{533} & \multirow{2}{*}{$\begin{array}{l}\text { El Karamny } \\
\text { et al., (2013) }\end{array}$} \\
\hline $\operatorname{MecA}(\mathrm{R})$ & 5' AGTTCTGCAGTACCGGATTTGC'3 & & \\
\hline
\end{tabular}

Table 6: Enterotoxin Production of MRSA strains.

\begin{tabular}{cccccccc}
\hline \multirow{2}{*}{ No. of tested strains } & \multicolumn{2}{c}{+ ve } & \multicolumn{2}{c}{-ve } & \multicolumn{2}{c}{ Enterotoxin } \\
& No. & $\%$ & No. & $\%$ & A & C \\
\hline 4 & 3 & 75 & 1 & 25 & 2 & 1 \\
\hline
\end{tabular}




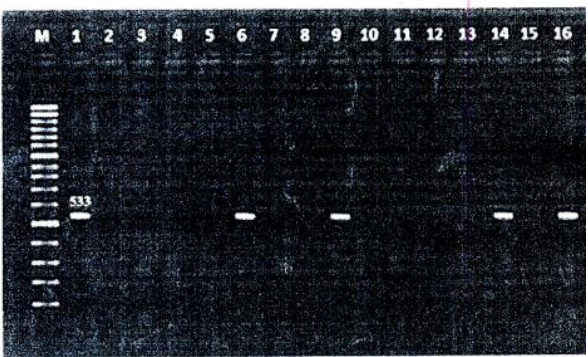

Photograph (1): Agarose gel electrophoresis of PCR amplification products of mecA gene for characterization of Methicillin Resistant Staphylococcus aureus (MRSA).

Lane M: $100 \mathrm{bp}$ ladder as molecular size DNA marker.

Lane 1: Control positive Staph. aureus for mecA gene.

Lane 2: Control negative.

Lanes 6, 9, 14 and 16: Positive Staph. aureus strains mecA gene.

Lanes 3, 4, 5, 7, 8, 10, 11, 12, 13, 15: Negative Staph. aureus strains for mecA gene.

\section{DISCUSSION}

From the standpoint of microbiology, fish and related products are a risk foodstuff group. The handling of fish products during the manufacturing process involves a risk of contamination by Staph.aureus (Shena and Sanjacv, 2007). The mean content of sodium chochide in salted Hydrocynus froskalli is 15.69 (Abd-Allah, 2006). This microorganism could be associated with salt (Hansen et al., 1995) or the fish (Ferreira et al., 2007) used in the processing.

Data shown in table (1) revealed that 34 isolates of Staph.aureus were recovered from the examined samples of molouha (50) with a percentage of $68 \%$, it is obvious from the same table that $16(32 \%)$ of the isolates were coagulase positive, while 18 (36\%) of them were coagulase negative, such high results for Staph.aureus isolation from molouha samples could be explained by the effect of salt concentration upon Staph.aureus, however Branescu and Stirbu (2008) concluded that Staph.aureus didn't affected by high concentrations of sodium chloride during its growth. Also Vishwanath, et al. (1998) reported that staphylococci can grow best in salty and low water activity-containing foods in which the competing organisms are in reduced numbers.

Higher results were recorded by Ezzeldeen, et al. (2011) who reported that Staph.aureus was isolated from $90 \%$ and $83.3 \%$ from low salt molouha and high salt molouha respectively, and lower results were recorded by Daniel, et al. (2012) who could isolate the organism from $27 \%$ of examined salted fish samples.

It is obvious from table (2) that the mean value of the organism was $35 \times 10^{3} \mathrm{cfu} / \mathrm{g}$ such result was lower than that obtained by Ezzeldeen (2011) who concluded that the mean counts of Staph.aureus in low salt molouha and high salt molouha were $2.33 \times 10^{5} \mathrm{cfu} / \mathrm{g}$ and $2.55 \times 10^{5} \mathrm{cfu} / \mathrm{g}$ respectively, and lower result was obtained by Edris, et al. (2014) who revealed that the average of Staph.aureus count in the examined samples of molouha was $6.79 \times 10^{2} \mathrm{cfu} / \mathrm{g}$ we can assume that high count and percentage of isolation for Staph.aureus among molouha samples were due to the contamination of fish during capture and subsequent unhygienic handling and processing. Albuquerque, et al. (2007) reported that high population of these bacteria indicates the degree of the spoilage it might have undergone.

Table (2) showed that $46 \%$ of positive samples of molouha for Staph.aureus had count higher than the limits allowed by (EOS, 2005), while Edris et al. (2014) reported that $26.67 \%$ of the examined samples of molouha was unaccepted.

Results explained in Table (3) clearly indicated that, coagulase positive Staph. aureus isolates showed resistance to neomycin, penicillin, kanamycin, amplicillin, chloramphenicol, erythromycin, oxytetracycline, cloxacillin, sulphamethoxazol, ciprofloxacin, cephalothin, gentamicin, methicillin and vancomycin with a percentage of $100,100,93.7$, $81.3,75.0,62.5,56.3,56.3,50.0,43.7,37.5,25.0$, 25.0 and 6.3 respectively, whereas the high resistance rate was observed against neomycin and penicillin $(100 \%)$ and the isolates showed 11 different patterns of antimicrobial sensitivity, whereas the higher sensitivity rate was observed with vancomycin $(87.5 \%)$. Concerning penicillin, similar data was reported by Daniel, et al. (2012) who found that all isolates from fishery products were resistant to pencicillin, while Sergelidis, et al. (2012) reported that only $59.1 \%$ of Staph. aureus isolates were resistant to penicillin.

The results of neomycin resistance test disagreed with. Malinowski, et al. (2002) and Ezzeldeen (2011) who found that $90.2 \%$ and $96.6 \%$ of Staph.aureus isolates were sensitive to neomycin. In this study, it was found that $81.3 \%$ of the isolates were resistant to ampicillin, this results was similar to what achieved 
by Daniel, et al. (2014) who recorded that $85.7 \%$ of Staph. aureus isolates were resistant to ampicillin, and higher rate of resistance (94\%) was recorded by Daniel, et al. (2012).

Ezzeldeen (2011) found that 20\% of Staph. aureus isolates were resistant to erythromycin, it was lower than that obtained in this study, while nearly similar results $(71.4 \%)$ was obtained by Daniel, et al. (2014). On the other hand, results showed that $37.5 \%$ of coagulase positive Staph. aureus isolates were sensitive to ciprofloxacin, while Ezzeldeen (2011) found that all isolates were susceptible to that antimicrobial agent.

Also data revealed that $56.3 \%$ of the isolates were sensitive to gentamicin, this result disagreed with Ezzeldeen (2011) who reported that $97.9 \%$ of Shaph.aureus strains were sensitive to the same antimicrobial agent, while Deniel, et al. (2014) found that $57.1 \%$ of Staph. aureus isolates were resistant to gentamicin. Moreove the resistance rate of the isolates against methicillin was $25 \%$. In addition the higher sensitive rate was observed toward vancomycin $(87.5 \%)$.

Hiramatsu, et al. (2001) suggested that vancomycin has been the most reliable therapeutic agent against infections caused by methicillin resistant Staph. aureus.

Antimicrobial resistance profile of coagulase positive Staph. aureus strains explained in Table (4) depending on Multiple Antibiotic Resistance (MAR) index which determined according to the formula stipulated by (Singh et al., 2010).

MAR index $=$ No. of resistance $/$ Total No. of tested antibiotics

It was found that one strain was resistant to all tested antibiotics, with (MAR) index 1, and three strains were resistant to all tested antibiotics except vancomycin, with (MAR) index 0.928, while one strain was resistant only to neomycin and penicillin with (MAR) index 0.143, other strains showed variation in their resistance against the tested antibiotics according to their (MAR) index. The emergence of multi-drug resistant pathogens is recognized as an environmental hazard to the food supply and human health, as it makes eradication more difficult and incidence to increase Popovich, et al. (2007).

In Egypt, most of fish farmers operate on a small scale basis with little technical support and apply treatment rather than prevention as the antibiotics are largely available with little regulation on the use in aquaculture, this can exert selective pressure on bacteria and stimulate the proliferation of strains having resistance to drugs and probable evolution of
Staph. aureus to methicillin-resistant Staph. aureus (MRSA) (Gaze, et al., 2008).

Additionally Tanaka, et al. (1995) reported that the extensive use of a group of beta-lactam antibiotics to counteract MRSA infection seems to be responsible for transition of MRSA types.

Detection of MecA gene done for all coagulase positive Staph. aureus strains (16) by PCR using oligonucleotide primer of mecA gene which was amplified 4 bands with amplified length of $533 \mathrm{pb}$, the ultraviolet illumination results explored that all (MRSA) four isolets were positive for presence of $m e c A$ gene.

Enterotoxin production of mecA gene Positive isolets were illustrated in Table (6), it was found that one of them could not produce any enterotoxin, while two types could produce SEA, and one could produce SEC.

Stengel (1990) reported that Staph.aureus is still a major cause of food poisoning due to ingestion of enterotoxins, the ability to produce such exterotoxins in food is more likely when competing microorganisms were absent (Frazier and westhoff, 1984), these competing organisms are in reduced number in salty and low water activity-containing foods, while Staphylococci can grow best in this food (Vishwanth et al., 1998).

Pedro, et al. (2004) stated that an improper storage or processing can enable SEs to be formed, and the risk could be increased if the shelf-life is long as in case of salted products.

Classical staphylococcal enterotoxins (SEA-SEE) have been reported to cause $95 \%$ of staphylococcal food poisoning, among them SEA is the most common in staphylococcus -related food poisoning (Pinchuk et al., 2010).

\section{CONCLUSIONS AND RECOMMENDATIONS}

The presence of Methicillin resistant Staph.aureus in ready to eat foods such as salted fish (molouha), represents a potential threat for the acquisition of antimicrobial resistant genes by those who eat or handle those foods. However the application of good manufacturing and hygiene practices along the salting processes seems to be a rule of thumb to prevent microbial spread and to eliminate the transfer of antimicrobial resistance genes through this type of food

\section{REFERENCES}

Abd-Allah, S.M.S. (2006): Egyptian traditional salted fishes: Processing Technology and quality 
monitoring. Ph.D. Thesis, Faculty of vet. Med., Assiut Mni.

Albuquerque, W.F.; Macae, A.; Sousa, O.V.; Vieira, G.H.F, and Vieria, R.H.S. F. (2007): Multiple drug resistant staphylococcus aureus strains isolated from a fish market and from fish handlers. Braz. J. Microbiol. 38 (1): 131-134.

APHA (2001): Compendium of methods for the microbial examination of foods. 3rd Ed. American public health association. Washington Dc. USA.

Baired - Parker A.C. (1980): Methods for identificating Staphyloccoci and micrococci. In F.A. Skinner and O.W. Lovelock: Identification methods for microbiologists. $2^{\text {nd }}$ Ed. Academic Press. Cambridge: 201-210.

Branescu, G. and Stirbu, C. (2008): The growth patterns of Escherichia coli and staphylococcus aureus in varied concentrations of sodium chloride cultures. Revista-Romanade Medicinav-etrinara, 18 (1): 81-86.

Daniel, D.; Lopez-cabo, M.; Saa-Ibusquiza, P. and Rodriguez-Herrera, J. (2012): incidence and characterization of staphylococcus aureus is fishery products markted in Galicia (Northwest spain). Int. J. Food Microbiol. 157 (2): 286-296.

Daniel, S.; Amin, A.; Papadopoulos, T.; Soultos, N.; Martziou, E.; Kaulaurida, V.; Govaris, A.; Pexara, A.; zdragas, A. and Papa, A. (2014): Isolation of methicicillin -resistant staphylococcus spp.from ready to eat fish products. Letters in Applied Microbiology 59: 500-506.

Deresse D.; Solomon, G. And Dawit, Y. (2012): Antibiotic resistance Staphylococcus aureus isolated from cow's milk in the Hawassa area, South Ethiopia. Ann. Clin. Microbiol. and Antimicrobials, 11: 26-34.

Doškar, J.; pantůček, R.; Růžičková, V. and Sedláček I. (2010): Molecular diagnostics of Staphylococcus aureus in, detection of bacteria, viruses, parasites and fungi. Springer, 139-184.

Edris, A.A.; Amin, A.R.; Naseif, Z.M. and Abdelfatah, M.E. (2014): Evaluation of retiled salted fish according to Egyptian Standard. Benha Veterinary Medical Journal 27 (2): 168-176.

El Karamany, I.; Ibrahim, Y.; Abouwarda, A.; Essam, A.; and Amin, M. (2013): Detection of high levels of methicillin and multi-drug resistance among clinical isolates of Staphylococcusaureus. Afr. J. Microbiol. Res.

EOS (2005): Egyptian organization for standardization and quality control, (1725/3) for molouha.

Ezzeldeen, A.N.; Mansour, A.H. and Ahmed, A.A. (2011): Phenotypic and molecular identification of staphylococcus aureus isolated from some Egyptian salted fish.
World applied Sciences Journal 15 (12): 1703 1712.

Feldhusen, F. (2000): The role of seafood in bacterial food borne diseases. Microbe Infection 2: 1651-1660.

Ferriera, J.G.; Hawkins, A.J.S. and Bricker, S.B. (2007): Management of productivity, environmental effects and profitability of shellfish aquaculture-the farm Aquaculture Resource Management (FARM) model. Aquaculture, 264: 160-174.

Fluit, A.; Verhoef, J. and Schmitz, F. (2001): Frequency of isolation and antimicrobial resistance of gram negative and gram positive bacteria from patients in intensive care units of 25 European university hospitals participating in the European arm of the SENTRY Antimicrobial Surveillance program 1997 1998. European Journal of Clinical Microbiology and Infectious Diseases 20; 617 -625 .

Frazier, W.C. and Westhoff, D.C. (1984): Tata McGraw Hill publisaing Co. Limited New York. U.S.A.

Gaze, W.; O'Neill, C.; Wellington, E. and Hawkey, P. (2008): Antibiotic resistance in the environment, with particular reference to MRSA. Advances in Applied Microbiology 63: 249-280.

Hansen, L.; Gill, T.; Truelstrup, T. and Huss, H.H. (1995): Effect of salt and storage temperature on chemical, microbioloical and sensory changes in cold-smoked salmon. Food Res. Int. 28: 123-130.

Hiramatsu, K.L.; Kuroda, M. and Ito. T. (2001): The emergence and evolution of methicillinresistant staphylococcus aureus. Trends Microbiol. 9: 486-493.

Huss, H.H. and Valdimarsson, G. (1990): Microbiology of saltedfish. Fish Tech News (FAO). 10: 3-5.

Livermore, D.M. (2000): Antibiotic resistance in Staphylococci. International Journal of Antimicrobial agents 16, 3-10.

Malinowski, E.; Klossowska, A.; Kaczmarowski, M.; Lassa, H. and Kuzma, K. (2002): Antimicrobial susceptibility of staphylococci isolated from affected mastitis cow.Bull. Vet. Inst. Pulowy, 46: 289-294.

Murkami K.; Minamide, W.; Wada, K.; Nakamura, E.; Teraoka, H. and watanabe, S. (1991): Identification of methicillin-resistant strains of Staphylococci by polymerase chain reaction. J. Clin Microbiol. 29(10): 2240-2244

"NCCLS" (National Committee for Clinical Laboratory Standards) (2001): Performance Standars for antimicrobial susceptibility testing. Supplement M100-S11. Villanova, PA, USA.

O'brien, F.; Lim, T.; Chong, F.; Coombs, G.; Enright, M.; Robinson, D.; Monk, A.; Said-Salim, B.; 
Kreiswirth, B. and Grubb, W. (2004): Diversity among community isolates of methicillin-resistant Staphylococcus aureus in Australia Journal of clinical microbiology. 42: 3185-3190.

Pedro, S.; Albuquerque, M.M.; Numes, M.L. and Bermardo, M.F. (2004): Pathogenic bacteria and indicators in salted cod (Gadus morhua) and desalted products at low and high temperatures. Journal of Aquatic Food Product Technology 13 (3): 39-48.

Perez-roth, E.F.; Claverie-Martin, J.V. and MendezAlvarez, S. (2001): Multiplex PCR for simultaneous identification of Staphylococcus aureus and detection of methiecillin and mupitocin resistance. J. Clin. Microbiol. 39 (11): 4037-4041.

Pinchuk, I.V.; Beswick, E.J. and Reyes, V.E. (2010): Staphylococcal Enterotoxins. Toxins 2, 2177 2197.

Popovich, K.J.; Hota, B. and Weinstein, R.A. (2007): Treatment of community associated methicillin-resistant staphylococcus aureus. Current Infectious Disease Reports 9: 398407.

Quinn, P.J.; Markey, B.K.; Carter, M.E.; Donnely, W.J.C.; Leonard, F.C. and Maguire, D. (2002): Veterinary microbiology and microbiological diseases. $1^{\text {st }}$ published Blackwell Sci. Ltd.

Rose, S.; Bankes, P. and Stringer, M. (1989): Detection of Staphylococcal enterotoxins in dairy products by the reversed passive latex agglutination (SET-RPLA) kit. Inter. J. Food Microbiol. 8(1): 65-72.

Sergelidis, D.; Abrahim, A.; Vasiliki, A.; Alexandros, G.; Theofilos, P. and Anna, P. (2012): prevalence, distribution and antimicrobial susceptibility of staphyloccus aureus in ready to eat salads and in the environment of a salad manufacturing plant in Northern Greece. Food Sci. 30: 285-291.
Shena, S.S. and Sanjacv, S. (2007): Prevalence of enterotoxigenic Staphylococcus aureus in fishery products and fish processing factory. Work food control. 18(12): 1565-1568.

Shewan, J.M. (1971): The microbiology of fish and fishery products. J. Appl. Bacteriol. 34 (2): 299-315

Singh, A.; Yadav, S.; Singh, S. and Bharti, P. (2010): Prevalence of Salmonilla in chicken eggs collected from poultry farms and markting channels and their antimicrobial resistance. Food Res. Inter., 43: 2027-2030.

Soliman, M.K.; EllaKany, H.F.; Gaafar, A.Y.; Elbialy, A.K.; Zaki, M.S. and Younes, A.M. (2014): Epidemiology and antimicrobial activity of methicillin-resistant Staphylococcus aureus (MRSA) isolated from Nile Tilapia (Oreochromis niloticus) during an outbreak in Egypt. Life Sci. J. 11(10): 1245-1252.

Stengel, G.F. (1990): Staphylococci, Fleisch wirtschaft 70 (3): 307-312.

Tanaka, T.; Okuzumi, K.; Iwamoto, A. and Hiramatsu, K. (1995): A retrospective study of mithicillin -resistant staphylococcus aureus clinical strains in Tokyo university hospital. Journal of Infection and chemotherapy 1: 4049.

Van, T.T.H.; Moutafis, G.; Tran, L.T. and Coloe, P.J. (2007): Antibiotic resistance in food borne bacterial contaminants in Vietnam. Applied and Environment Microbiology, 73(24): 79067911.

Vishwanath, W.; Lillabati, H. and Bijen, M. (1998): Biochemical nutritional and microbiological quality of frish and smoked mudeel fish Monopterusalbus: a comparative study. Food chemistry, 61 (1/2): 153-156.

Wulf, M. and Voss, A. (2008): MRSA in livestock animals -an epidemic waiting to happen? Clinical microbiology and infection.14; 519521. 


\section{مدى تواجد ميكروب المكور العنقودي الذهبي المقاوم للميثيُلين في الملوحة}

لبنح محمد إبرا هيم ، منال حسن ثابت

E-mail: ghada02468@yahoo.com_Assiut University web-site: www.aun.edu.eg

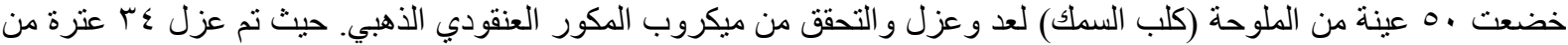

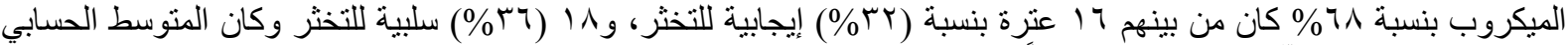

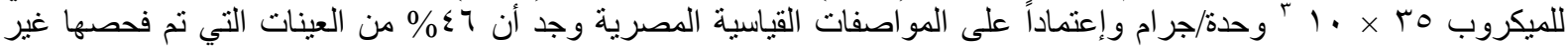

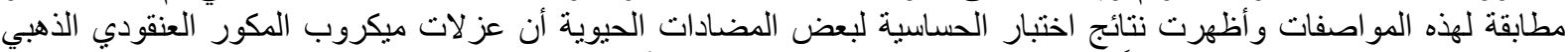

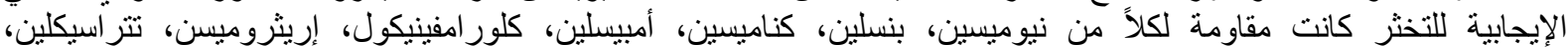

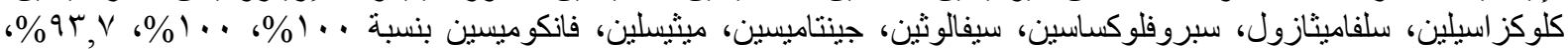

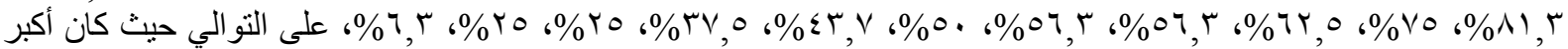

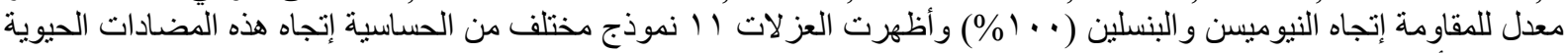

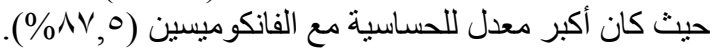

ولقد تم عمل اختبار البلمرة التأكيدي المتسلسل لكل عزلات الميكروب العنقودي الذهبي الإيجابية للتخثر باستخدام البادئ التمهيدي

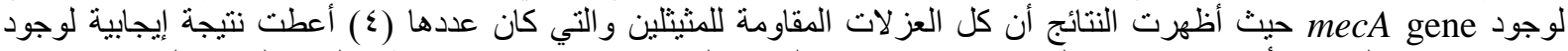
mecA gene ولقد وجد أن و احد من هذه العز لات لا توجد عنده القدرة على إنتاج enterotoxin و اثثنين لديهم القدرة على إنتاج بينما واحد لديه القدية على إنتاج 